\title{
UTICAJ SRPSKIH PREVODNIH EKVIVALENATA NA UOČAVANJE I KRATKOROČNU RETENCIJU ENGLESKIH KOLOKACIJA
}

\begin{abstract}
APSTRAKT: Cilj ovog istraživanja bio je da se ispita da li usmeravanje pažnje na kolokacije u novom tekstu pomoću srpskog prevodnog ekvivalenta engleske kolokacije doprinosi njihovom lakšem uočavanju u tekstu u odnosu na tehniku povezivanja ponuđenih engleskih kolokata pre obrade teksta ili čitanja i samostalnog uočavanja svih kolokacija u tekstu. Drugi cilj bio je da se ispita da li način usmeravanja pažnje na kolokacije u novom tekstu pomoću srpskog prevodnog ekvivalenta doprinosi boljoj kratkoročnoj retenciji novih kolokacija. Rezultati kvantitativnog istraživanja u kom je učestvovalo 32 ispitanika i u kom je analizirano 7 kolokacija tipa glagol imenica su pokazali da prevodni ekvivalent nema veći uticaj na uočavanje, kao ni na kratkoročnu retenciju kolokacija u odnosu na druga dva ispitivana načina.
\end{abstract}

Ključne reči: glagol+imenica, kolokacija, kratkoročna retencija, povezivanje, prevodni ekvivalent, strategije, tekst, uočavanje.

\section{THE EFFECT OF SERBIAN TRANSLATION EQUIVALENTS ON NOTICING AND SHORT-TERM RETENTION OF ENGLISH COLLOCATIONS}

\begin{abstract}
The aim of this paper was to examine whether providing the Serbian equivalent of English verb+noun collocations prior to reading the text has any advantages over other two attention-drawing techniques: matching the elements of target collocations prior to reading the text, and simply instructing students to look for all collocations in the text. The study also examined if providing the Serbian equivalent of English verb-noun collocations prior to reading the text produced more significant learning gains on the immediate test compared with the other two techniques. The research in which 32 participants took part and which examined 7 verb+noun collocations showed that the translation equivalent does not have a more significant influence on noticing collocations or short-term retention compared with the other two techniques.
\end{abstract}

Key words: verb+noun, collocation, short-term retention, matching, translation equivalent, strategies, text, noticing. 


\section{UVOD}

Kolokacija predstavlja uobičajen, a ponekad i redovan, dvočlani spoj jedne lekseme s nekom drugom (imenica+glagol, glagol+imenica, pridev+imenica, glagol+prilog, prilog+pridev i imenica+of, /genitiv + imenica), po pravilu unutar određene sintaksičke jedinice, a po svojoj suštini, ona čini sadržinsku, funkcijsku, a delom i formalnu celinu, koja pruža opis specifične mikrosituacije u vanjezičkoj ili jezičkoj stvarnosti. Kolokacije karakteriše minimalna zamenljivost, slaba postojanost, te prozirnost (Prćić 1997: 115-119). Sa aspekta kontrastivne analize kolokacije mogu biti kongruentne (sturkturno i leksički ekvivalentne u oba jezika) ili nekongruentne (neekvivalentne).

Razumevanje i pravilna upotreba kolokacija pored leksičke, gramatičke i pragmatičke kompetencije na stranom jeziku, predstavlja uslov za uspešnu komunikaciju. Međutim, neizvorni govornici, čak i na naprednim nivoima često upotrebljavaju neadekvatne ili neprihvatljive kolokacije (McCarthy 1990: 13). Znanje o tome šta je prihvatljiva kolokacija jeste sastavni deo jezičke kompetencije izvornog govornika, dok je za neizvorne govornike ovladavanje kolokacijama otežano, čak i na visokom nivou znanja jezika (Nesselhauf 2003: 237). U dosadašnjoj literaturi se kao razlozi nedostatka kolokacijske kompetencije navode nedostatak svesti o kolokacijama kao jednoj vrsti jezičkog spoja koja je često posledica prozirnosti kolokacije zbog čega ih učenici teže uočavaju (Laufer \& Waldman 2011), uticaj maternjeg jezika (Martynska 2004; Nesselhauf 2003), nedovoljna motivacija da se one savladaju u odnosu na druge fiksne jezičke spojeve (Ying \& O’Neill 2009 u Henriksen 2013: 41). Konačno, ne postoji jedinstven stav kada je reč o tome koji pristup je najefikasniji u razvijanju kolokacijske kompetencije, tj. koji pristup treba primenjivati u nastavi: holistički (usvajanje kolokacije kao celine) ili analitički (analiza kolokata).

Međutim, bez obzira na to za koji pristup se zalažu, svi autori ističu značaj usmeravanja pažnje na kolokacije. Stoga je cilj ovog rada bio da se ispita da li usmeravanje pažnje na nove kolokacije u tekstu pomoću srpskog prevodnog ekvivalenta engleske kolokacije doprinosi njihovom lakšem uočavanju u tekstu i njihovoj kratkoročnoj retenciji u odnosu na tehniku povezivanja ponuđenih engleskih kolokata pre obrade teksta ili tehniku čitanja i samostalnog uočavanja svih kolokacija u tekstu. Polazi se od pretpostavke da će nemogućnost davanja prevoda srpskih kolokacija, tj. narušen proces obrade informacija (cognitive failure), dovesti do metakognitivnog uspeha (metacognitive success) (Brown 1980 u Garner 1990: 518), jer će motivisati ispitanike da, pošto uoče problem, primene različite strategije (oslanjanje na kontekst ili jedan od kolokata) kako bi pronašli 
engleski ekvivalent $\mathrm{u}$ tekstu. Usredsređivanje pažnje na proveru odgovora omogućava učenicima da, ukoliko nisu dali očekivani odgovor, sami uoče grešku, uporede odgovore, uvide gde se nalazi problem, uoče eventualne razlike između maternjeg i stranog jezika i tako poboljšaju retenciju.

\section{FAKTORI KOJI OTEŽAVAJU USVAJANJE KOLOKACIJA}

Cilj dosadašnjih istraživanja u oblasti kolokacija u nastavi bio je da se ustanovi iz kog razloga ih učenici teže usvajaju, kao i da se utvrdi koji pristup u nastavi bi bio najefikasniji za prevazilaženje ovih poteškoća.

Pre svega, treba istaći da je uočeno da usvajanje kolokacija ne teče istim tempom kao usvajanje novih reči. Tačnije produktivno znanje kolokacija neizvornih govornika znatno zaostaje za produktivnim znanjem pojedinačnih reči (Laufer \& Waldman 2011: 651), a kada se radi o kolokacijskoj kompetenciji produktivno znanje zaostaje za receptivnim (Nation 2001: 325; Nesselhauf 2003: 223). Dakle, učenici nemaju poteškoća sa tumačenjem značenja kolokacija pod uslovom da su im značenja kolokata poznata, ali upravo zbog semantičke transparentnosti kolokacije se slabije uočavaju (Laufer \& Waldman 2011: 665).

Kao drugi uzrok teškoća u usvajanju kolokacija navodi se nepoklapanje strukture dvaju jezika usled njihovih specifičnosti (McCarthy 1990: 13; Bahns 1993). Poznato je da se učenici, naročito na nižim stupnjevima učenja jezika, oslanjaju na maternji jezik (J1). Dakle, neizvorni govornici prenose lekseme iz maternjeg jezika, ali kako zamenljivost kolokata nije posledica isključivo semantičkih osobina leksema, već je donekle arbitrarna i specifična za svaki jezik, dolazi do stvaranja nepostojećih kolokacija (Martynska 2004; Nesselhauf 2003: 235). Ispitujući produkciju kolokacije tipa glagol+imenica, Neselhauf je uočila da neizvorni govornici najviše poteškoća imaju sa kolokacijama sa srednjim nivoom restrikcije, tipa exert influence u odnosu na kolokacije u kojima postoji veći stepen restrikcije tipa fail an exam/test, kao i sa nekongruentim kolokacijama u odnosu na kongruentne (Nesselhauf 2003: 236). Iz ovoga bi se moglo zaključiti da samo nekongruentne kolokacije predstavljaju problem. Međutim, uočeno je da, iako učenici zaista prave više grešaka kada su u pitanju nekongruentne kolokacije, i kongruentne kolokacije mogu predstavljati problem (Nesselhauf 2003: 238; Yamashita \& Jiang 2010: 662). To znači da se greške ne mogu pripisati samo razlikama u jezicima. Moguće objašnjenje za ovaj fenomen jeste da, pošto razviju svest o postojanju razlika među jezicima, neizvorni govornici ne preslikavaju J1 (maternji jezik) u J2 (strani jezik), čak i onda kada je to moguće (Yamashita \& Jiang 2010: 662). Na kraju, treba pomenuti još dva afektivna faktora: nedostatak 
motivacije i samopouzdanje. Naime, Laufer i Valdman ističu da upotreba netačnih kolokacija u suštini ne ometa komunikaciju, bez obzira na to što govornik zvuči čudno, te da zadovoljstvo ostvarenom komunikacijom ne doprinosi tačnoj upotrebi jezika i razvijanju kolokacijske kompetentnosti (Laufer \& Waldman 2011: 666). Njihovo istraživanje pokazalo je da pored motivacije još jedan afektivni faktor, samopouzdanje, utiče na usvajanje kolokacija, ali negativno. Naime učenici srednjeg i višeg nivoa vladanja jezikom, češće upotrebljavaju netačne kolokacije, što autorke objašnjavaju višim stepenom samopouzdanja (Laufer \& Waldman 2011: 665).

\section{PRISTUPI OBRADI KOLOKACIJA U NASTAVI}

Kada je u pitanju pristup u nastavi kojim se kolokacije mogu najefikasnije usvojiti postoji nekoliko stavova. Jedan se odnosi na usvajanje kolokacija kao celina (holistički pristup). Ovaj stav zastupa Elis, oslanjajući se na psiholingvističke eksperimente koji pokazuju da ljudi brže i lakše obrađuju jezičke celine koje su usvojili nesvesnom analizom velikog inputa (Ellis 2003: 75). On dalje navodi Milera prema kom se količina informacija koja se skladišti u kratkoročnu memoriju, čiji je kapacitet konstantan i iznosi 5 do 9 jedinica, povećava ukoliko se pojedinačni elementi spoje u jednu veću celinu (Ellis 2003: 75) iz čega proizilazi da je kolokacije bolje učiti kao celine. Ovakav stav zastupaju i neki drugi autori (Martynska 2004; Durrant i Schmitt 2010; Makinina 2017; Macis \& Schmitt 2017: $55^{1}$ ), jer je uočeno da odrasli neizvorni govornici usvajaju kolokacije kojima su često izloženi. Istraživanje Duranta i Šmita pokazalo je, takođe, da kolokacije treba učiti kao celine, izlažući učenike što većem broju susreta sa istom kolokacijom u što kraćem vremenskom periodu. Suprotno njihovom očekivanju, ispitanici pokazuju bolje rezultate u retenciji kolokacija ukoliko se susreću sa istom kolokacijom u istom, a ne različitom rečeničnom kontekstu u kojoj bi kolokacija, po mišljenju autora, bila istaknuta time što bi jedino ona bila ista u različitom rečeničnom kontekstu. Autori navode da moguć razlog jeste taj da isti rečenični kontekst iziskuje manji kognitivni napor, te se kolokacija lakše pamti (Durrant i Schmitt 2010: 181,180). Nejšn predlaže memorisanje ovih jezičkih spojeva bez analize kolokata koji ih sačinjavaju u

\footnotetext{
1 Ova dva autora smatraju da treba koristiti analitički pristup ukoliko kolokacija nije idiomatizovana, npr. top drawer=uppermost drawer, naspram idiomatizovanog top drawer=something that is best of its class, str. 51.
} 
okviru razvijanja jezičke kompetencije kroz veštine slušanja, govorenja, čitanja i pisanja, naročito na nižim nivoima učenja jezika. Drugi način jeste da učenici memorišu ove jezičke spojeve, ali usmerenim (deliberate) podučavanjem kroz vežbe kao što su povezivanje kolokata, i uz razvijanje svesti kod učenika o postojanju različitih tipova kolokacija (Nation 2001: 336, 343).

Druga grupa autora zalaže se za analitički pristup obradi kolokacija, i eksplicitno učenje, što podrazumeva svest u toku učenja (pokušaj da se razume funkcija određene jezičke forme), (Hulstijn 2003: 360). Tako Rej, oslanjajući se na rezultate različitih istraživanja ustaljenih fraza (formulaic sequences), naročito na zapažanja Vilisa (Rej u ličnoj komunikaciji sa Vilisom, Wray 2000: 484), zaključuje da svaki spoj koji dopušta zamenljivost jednog elementa ili morfološku transformaciju treba analizirati, jer učenici stranog jezika ne usvajaju jezik na isti način kao i izvorni govornici, i imaju želju i sposobnost da analiziraju jezičke spojeve kako bi bolje organizovali materijal koji treba da usvoje (Wray 2000: 484). Liu ističe da usmeravanje pažnje na značenje kolokata poboljšava retenciju, u odnosu na prosto memorisanje velikog broja kolokacija (Liu 2010: 21, 15, 27). Neselhauf takođe predlaže eksplicitnu nastavu, ali ističe da pažnju ispitanika nije dovoljno samo usmeriti na razlike, već i sličnosti u stranom i maternjem jeziku (Nesselhauf 2003: 23).

Važno je istaći da, bez obzira na to za koji pristup se zalažu, autori ne umanjuju značaj što češćeg susretanja učenika sa kolokacijama koje uče.

Kada su u pitanju metode koje se mogu primenjivati Laufer i Girzai ističu značaj prevođenja $\mathbf{J} 2$ kolokacija na $\mathrm{J} 1$, u odnosu na čitanje teksta i uočavanja kolokacija, i čitanje teksta bez bilo kakvih prethodnih instrukcija (Laufer \& Girsai 2008). Za isticanje sličnosti i razlika između J1 i J2 zalažu se Jamašita i Jiang, koji smatraju da se učenici oslanjaju na J1 sve dok ne automatizuju znanje kolokacija (Yamashita \& Jiang 2010: 663). Piters ističe značaj tipografskog isticanja kolokacija u tekstu, jer se na ovaj način usmerava pažnja učenika na ciljne kolokacije (Peters 2012: 75). Do istog zaključka došla je i Laufer, ispitujući ulogu korišćenja rečnika u usvajanju kolokacija (Laufer 2011: 43). U istom istraživanju uočila je i da upotreba rečnika doprinosi retenciji kolokacija, naročito na srednjem nivou učenja jezika, jer razvija svest o jezičkoj strukturi (Laufer 2011: 45). Jedno istraživanje pokazalo je, na osnovu odgovora ispitanika, da isticanje kolokacija u nastavi navodi učenike da nadalje i sami traže nove kolokacije u svakom tekstu koji čitaju (Dorkchandra 2015: 7). 


\section{METODOLOGIJA ISTRAŽIVANJA}

Ovaj rad zasniva se na stanovištu da u nastavi treba zastupati eksplicitnu nastavu, kao i na Šmitovoj tvrdnji da nema učenja bez pažnje i primećivanja (Schmidt 1993: 209). Kako učenici često ne uočavaju kolokacije zbog njihove transparentnosti, neophodno je skretanje njihove pažnje na nove kolokacije. Još jedno polazište jeste značaj učešća i udubljivanje učenika u zadatak (The Involvement Load Hypothesis). Naime, stepen motivacije učenika da nauči nepoznatu reč, potreba za određenom rečju i manipulisanje jezičkim materijalom doprinosi boljoj retenciji (Hulstijn \& Laufer 2001). Kako se vidi iz prethodnog odeljka, do sada je ispitivan uticaj prevodnih ekvivalenata na usvajanje engleskih kolokacija (Laufer \& Girsai 2008), ali ne i uticaj prevodnog ekvivalenta na uočavanje kolokacija u tekstu. Međutim, prema zapažanju velikog broja studenata, prevodni ekvivalenti engleskih kolokacija doprinose njihovom boljem uočavanju, jer studenti nisu svesni da često ne znaju da kombinuju reči sve do trenutka kada treba da prevedu kolokaciju sa srpskog (J1) na engleski jezik (J2). Postavlja se pitanje da li će prezentovanje prevodnog ekvivalenta engleske kolokacije (koja je ispitanicima nepoznata, ali značenje pojedinačnih kolokata jeste), u dovoljnoj meri motivisati ispitanike da nađu engleski leksički spoj koji ima istu semantiku kao srpska kolokacija, te da li će kognitivni procesi koje uključuju u zadatak poboljšati retenciju u odnosu na druga dva načina usmeravanja pažnje. Zadatak povezivanja kolokata sa ciljem da se formiraju moguće kolokacije pre obrade novog teksta koji se često sreće u udžbenicima koji se koriste na studijama (Market Leader), koji zahteva tumačenje značenja engleskih kolokata i na osnovu toga stvaranje mogućeg spoja, te proveru odgovora u samom tekstu; i drugi, davanje instrukcija studentima da pronađu sve kolokacije u toku čitanja teksta, gde je pažnja isključivo usmerena ciljem zadatka. Postavljena su dva pitanja:

1. Da li prevodni ekvivalenti kolokacije tipa glagol+imenica doprinose boljem uočavanju novih kolokacija u tekstu?

2. Da li usmeravanje pažnje na nove kolokacije prevodnim ekvivalentima pozitivno utiče na kratkoročnu retenciju u odnosu na druge načine usmeravanja pažnje na kolokacije?

U istraživanju je učestvovalo 32 ispitanika, od toga 12 studenata i 20 studentkinja prve godine studija Visoke poslovne škole u Novom Sadu. Ispitanici su nasumično podeljeni u tri grupe (prva (eksperimentalna) grupa 11 ispitanika, druga 10 i treća 11 ispitanika). Na početku istraživanja, ispitanici su obavešteni da će biti testirani. Istraživanje je trajalo oko 60 minuta, bilo je anonimno i svi 
ispitanici su dobrovoljno pristali da u njemu učestvuju, ali nijedan ispitanik nije pristao na kvalitativnu analizu. Stoga je razgovor sa celom grupom ispitanika preostao kao jedini mogući način da se pouzdanije (donekle) protumače rezultati, tj. da se utvrdi koje strategije su ispitanici koristili u toku izrade zadataka. Nedostaci razgovora sa celom grupom ispitanika su činjenica da anksioznost utiče na mnoge ispitanike - osećaju se nelagodno da pred celom grupom iskažu svoje mišljenje. S druge strane, mnogi ispitanici ne pokušavaju da razmisle o tome šta ih je navelo da daju određen odgovor i namesto toga se jednostavno slažu sa izrečenim stavom nekog od ispitanika. Stoga treba imati u vidu da mnogi odgovori nisu do kraja rasvetljeni.

$\mathrm{U}$ istraživanju je korišćen tekst, a ne izdvojene rečenice, jer se studenti u nastavi najčešće susreću po prvi put sa novom kolokacijom u toku aktivnosti čitanja i slušanja. Za ovo istraživanje korišćen je tekst preuzet sa interneta Seven Steps To Running The Most Effective Meeting Possible, pod pretpostavkom da je svim ispitanicima nepoznat. Tekst je unekoliko izmenjen kako bi odgovarao nivou znanja studenata (Dodatak 1).

$\mathrm{Za}$ istraživanje je odabrano 7 kolokacija u tekstu tipa glagol+imenica. Odabrane su kolokacije: run a meeting, seek input, reach a decision, stick to the schedule, create an agenda, delegate tasks, establish rules. Ove kolokacije odabrane su na osnovu dva kriterijuma. Kao prvo, ove kolokacije su na osnovu iskustva istraživača učestale u engleskom poslovnom jeziku. Drugo, test dopunjavanja kolokacija glagolom u prethodnoj generaciji pokazao je da studenti na početku prve godine ne znaju ove kolokacije. Kako bi bilo nemoguće proveriti da li su ove kolokacije nepoznate i svim ispitanicima u ovom uzorku, a da se ne naruši validnost istraživanja, jer bi dodatan susret sa ovim kolokacijama uticao na njihovo uočavanje, pošlo se od pretpostavke da je situacija u ovom uzorku ispitanika ista ili slična onoj iz prethodne generacije studenata. Stoga su u eksperimentalnoj (prvoj) grupi analizirani odgovori kako bi se eliminisale poznate kolokacije u ovom uzorku ispitanika. Ipak, teško je utvrditi input svakog pojedinca (Durrant i Schmitt 2010: 170) ili kako piše Hulstijn, ukoliko su ispitanici već učili strani jezik, veoma je teško isključiti mogućnost da neke reči ispitanici (bar delimično) znaju (Hulstijn 2003: 370).

Najpre se od cele grupe tražilo da navedu kolokacije tipa glagol+imenica koje su zapamtili sa prethodnih časova kako bi se osiguralo da svi ispitanici razumeju šta treba da urade u zadatku. Dobijeni su odgovori (pay attention, do sports, give lectures, arrange a meeting, run a workshop i have lunch) koji su zapisani na tabli. 
Ispitanici su nasumično podeljeni u 3 grupe. Prva grupa studenata dobila je najpre listić sa srpskim prevodnim ekvivalentima 7 kolokacija koji odgovaraju kontekstu: run a meeting, seek input, reach a decision, stick to the schedule, create an agenda, delegate tasks, establish rules (voditi sastanak, tražiti nečije mišljenje, doneti odluku, pridržavati se plana, sastaviti dnevni red, dodeliti zadatke, odrediti pravila). Odabran je prevodni ekvivalent koji odgovara kontekstu. Prvi zadatak ispitanika bio je da prevedu na engleski jezik date kolokacije na više načina ukoliko je to moguće. Cilj ovog zadatka bio je da se usmeri pažnja ispitanika na ciljne kolokacije, ali i da se proveri da li su ispitanicima zaista ciljne kolokacije nepoznate, tačnije da li imaju produktivno znanje ovih kolokacija. Pošto su listići sa odgovorima sakupljeni, ispitanici su ponovo dobili listu engleskih kolokacija na srpskom, odštampan tekst i zadatak da pronađu i obeleže u datom tekstu kolokacije čije srpske prevodne ekvivalente su imali pred sobom. Druga grupa dobila je listić sa engleskim kolokatima ciljnih kolokacija datim u dve kolone i zadatak da povezivanjem ponuđenih kolokata pokušaju da formiraju ciljne kolokacije, a zatim provere odgovore u tekstu. Treća grupa ispitanika dobila je samo instrukcije da pročita tekst i obeleži sve kolokacije tipa glagol+imenica.

Pošto su predati listovi sa tekstom, tekst je projektovan na platnu. Istraživač je postavljao pitanja u vezi sa tekstom sa ciljem da se ponove kolokacije (npr. What is the first tip for running a successful meeting?) ili navodeći ispitanike da koriste ciljne kolokacije (npr. What should you do before closing the meeting?Delegate tasks, set deadlines). Provereno je i da li svi razumeju značenje manje frekventnih reči u sklopu kolokacija (npr. agenda, input) ili cele kolokacije (npr. establish rules). Od studenata se zahtevalo i da pokušaju da prenesu značenje kolokacije na drugačiji način ukoliko misle da je to moguće kako bi bili sigurni da je i taj drugi predloženi oblik prihvatljiv.

Kako je cilj ovog istraživanja bio da se utvrdi efekat različitih načina usmeravanja pažnje, ispitanici su testirani samo testom kratkoročne retencije, jer kako piše Hulstijn (2003: 372) davanjem testa direktno nakon obrade novog gradiva mere se efekti kognitivnih procesa za vreme obrade, dok se odloženim testovima meri efekat ponavljanja, zadržavanja materijala i zaboravljanja, jer dugoročno pamćenje zahteva često ponavljanje. Neposredno posle obrade ispitanici su umesto teksta dobili 7 rečenica (Dodatak 2), ali različitih od onih koje su se javile u tekstu i ukupno 14 glagola (od toga 7 distraktora). Zadatak ispitanika bio je da upišu glagole koji nedostaju. U zadatku u kojem je trebalo da ispitanici podvuku ili zaokruže uočenu kolokaciju u tekstu, u nekim slučajevima nisu označena oba kolokata. Takvi odgovori smatrani su netačnim. 
Dobijeni podaci obrađeni su metodom deskriptivne analize i testom jednofaktorske analize varijanse u paketu SPSS13.0.

\section{REZULTATI I DISKUSIJA}

\subsection{Analiza prevodnih ekvivalenata srpskih kolokacija}

Rezultati prvog zadatka u prvoj grupi proanalizirani su iz dva razloga. Odgovori u ovoj grupi poslužili su da se utvrdi da li su i u ovom uzorku ispitanika ciljne kolokacije studentima zaista nepoznate, jer, kako je već u prethodnom odeljku istaknuto, veoma je teško utvrditi prethodni input svakog pojedinca. Po završetku istraživanja istraživač je postavio pitanje da li je neko znao neke od kolokacija. Nekolicina studenata je rekla da jeste (reach a decision i stick to the schedule), ali se ne bi setili da ih upotrebe, dakle nemaju produktivno znanje ovih kolokacija. Drugi cilj analize ovih odgovora bio je da se proveri da li se ispitanici zaista u velikoj meri oslanjaju na J1. Uočava se, očekivano, da se ukoliko ne znaju tačan odgovor, ispitanici oslanjaju na maternji jezik i doslovno prevode kolokate, npr. ask someone's opinion, bring a decision, respect a plan. Međutim, već letimičnim pregledom odgovora uviđa se da ovakve greške ne preovladavaju. Ispitanici su se mahom trudili da prenesu značenje srpske kolokacije (npr. ask for someone's opinion, give duties/tasks). Mada je najčešće problem odabir sekundarnog kolokata u ovoj vrsti spojeva, u jednom slučaju (stick to the schedule) uočava se da i primarni kolokat može biti uzrok poteškoća. Važno je naglasiti, da nijedan ispitanik nije dao bar dva moguća rešenja za jednu srpsku kolokaciju. Prevodi kolokacija na engleski jezik ispitanika prve grupe dati su u Tabeli 1.

\begin{tabular}{lll}
\hline PREVODNI EKVIVALENT & OČEKIVAN PREVOD & ODGOVORI ISPITANIKA \\
\hline VODITI SASTANAK & RUN A MEETING & Lead a meeting (6) \\
& & Hold a meeting (3) \\
& & Schedule a meeting (2) \\
\hline TRAŽITI NEČIJE & SEEK INPUT & Ask for someone's opinion \\
MIŠLJENJE & & $(5)$ \\
& & Look for someone's opinion \\
& & $(5)$ \\
\hline DONETI ODLUKU & REACH A DECISION & $-(1)$ \\
& & Make a decision $(8)$ \\
& & Take a decision (1) \\
& Bring a decision (1) \\
& Make a choice (1) \\
\hline
\end{tabular}




\begin{tabular}{lll}
\hline PRIDRŽAVATI SE & STICK TO THE & Follow the plan (1) \\
RASPOREDA & SCHEDULE & Stick to the plan (2) \\
& & Respect the plan (2) \\
& & Keep to the schedule (2) \\
& & $-(4)$ \\
\hline SASTAVITI DNEVNI RED & CREATE AN AGENDA & Make a plan (4) \\
& & Make a schedule (2) \\
& & Arrange an agenda (1) \\
& & Make an agenda (2) \\
\hline DODELITI ZADUŽENJA & DELEGATE TASKS & Make a day list (1) \\
& & $-(1)$ \\
\hline ODREDITI PRAVILA & ESTABLISH RULES & Give duties (1) \\
& & Give tasks (7) \\
& & $-(3)$ \\
\hline
\end{tabular}

Tabela 1. Ispitivane kolokacije i prevodi ispitanika prve grupe

Kako se iz Tabele 1. vidi za neke kolokacije dati su mogući engleski ekvivalenti (npr. lead a meeting, make a decision, keep to the schedule, make a plan, make rules, organize a meeting, arrange a meeting) prema rečnicima Oxford Collocation Dictionary i Longman Online Dictionary.

\subsection{Uočavanje kolokacija u tekstu}

Kada se radi o uočavanju kolokacija u tekstu rezultati pokazuju da postoji razlika među grupama, tj. postoji statistički značajna razlika u uočavanju ispitivanih kolokaciju među grupama $(\mathrm{N}=32, \mathrm{p}=.002, \mathrm{~F}(2,29)=7.631)$. Naknadna poređenja (1. grupa $\mathrm{M}=4.00 \mathrm{SD}=.77 ; 2$. grupa $\mathrm{M}=5.10 \mathrm{SD}=1.59$; 3 . grupa $\mathrm{M}=$ $2.90 \mathrm{SD}=1.37)$, međutim, pokazuju da postoje statistički značajne razlike samo između druge $i$ treće grupe ispitanika $(p=.001)$, te se može zaključiti da srpski prevodni ekvivalenti ne doprinose značajno boljem uočavanju novih kolokacija $u$ tekstu. Između prve i druge grupe ne uočava se značajna razlika. Bolji rezultat u drugoj grupi mogao bi se objasniti time što je ispitanicima u ovoj grupi, kao i u prvoj grupi, usmerena pažnja samo na ciljne kolokacije. Ispitanici u drugoj grupi bili su u prilici da zaključe koji su mogući spojevi oslanjanjem na postojeće znanje značenja kolokata, te da ih pronađu $u$ tekstu i provere odgovor. Uz to, ispitanici $u$ drugoj grupi imali su pred sobom listu engleskih kolokata pa su mogli da ih koriste 
kao signal u traženju tačnih spojeva, čak i ako nisu znali tačno značenje kolokata. Slično tome, ispitanici prve grupe imali su pred sobom listu prevodnih ekvivalenata engleskih kolokata, te su traženjem mogućih engleskih ekvivalenata i proverom spojeva u kontekstu mogli lakše uočiti spoj u tekstu. Ispitanicima u trećoj grupi jedina mogućnost bila je da se oslone na značenje poznatih leksema i kontekst. Možemo zaključiti da je zadatak u trećoj grupi iziskivao veći kognitivni napor. U Tabeli 2. dat je broj uočenih ciljnih kolokacija po grupama.

\begin{tabular}{lllll}
\hline Kolokacija & $\begin{array}{l}\text { Prva } \\
\text { grupa }\end{array}$ & Druga grupa & Treća grupa & UKUPNO \\
\hline RUN A MEETING & 10 & 8 & 8 & 26 \\
\hline SEEK INPUT & 3 & 6 & 3 & 12 \\
\hline REACH A DECISION & 4 & 9 & 4 & 17 \\
\hline STICK TO THE & 7 & 8 & 8 & 23 \\
SCHEDULE & & & & 20 \\
\hline CREATE AN AGENDA & 8 & 7 & 5 & 15 \\
\hline DELEGATE TASKS & 6 & 6 & 3 & 14 \\
\hline ESTABLISH RULES & 6 & 5 & 3 & 127 \\
\hline UKUPNO: & 44 & 49 & 34 & \\
\hline
\end{tabular}

Tabela 2. Broj uočenih ciljnih kolokacija po grupama

Najbolji rezultati uočavaju se u drugoj grupi ispitanika čiji zadatak je bio povezivanje kolokata, a nešto lošiji skor u eksperimentalnoj grupi. Kolokacija seek input predstavljala je većini ispitanika prve i treće grupe najveći problem jer, kako kažu, nisu znali reč input, a neki nisu znali ni reč seek. Mada se u literaturi može naći da nepoznate reči privlače veću pažnju u odnosu na poznate (Peters 2012: 76) u ovom slučaju većina ispitanika nije uočila kolokaciju. Izuzetak su, čini se, studenti koji bolje vladaju jezikom (dva takva ispitanka su objasnila strategiju koju su koristili). Oni su pomoću strategije zaključivanja značenja cele kolokacije kao bilo koje druge lekseme na osnovu konteksta uočili kolokaciju u tekstu. U drugoj grupi jedan ispitanik kaže da je i pre čitanja teksta došao do tačnog rešenja sistemom eliminacije. Strategije oslanjanja na prethodno znanje jednog kolokata koristili su i neki ispitanici prve grupe. Na primer, tražili su reči zadatak (task) i pravila (rules) pa su tako uočili glagol sa kojim ove dve imenice kolociraju. Važan je odgovor ispitanika prve grupe koji kaže da je razumeo rečenicu, ali je očekivao reč opinion ili view, što pokazuje da ispitanici koriste kognitivnu strategiju predviđanja. U sve tri grupe primećuje se relativno dobar rezultat u uočavanju kolokacije stick to the schedule, create an agenda. Ispitanici u trećoj grupi rekli su 
da su najlakše uočili kolokaciju stick to your schedule, jer se nalazi na početku pasusa. Međutim, lošiji rezultati se uočavaju kada su u pitanju kolokacije u kojima su kolokati bili formalno razdvojeni pridevom establish ground rules i izmenjenim oblikom glagola (prošli particip umesto infinitiva tasks delegated). Iznenađuje da je u drugoj i trećoj grupi manji broj ispitanika uočio kolokaciju run a meeting, iako se navedena kolokacija javila i u naslovu. Moguće je da je i ovde formalna razdvojenost kolokata uticala na to da je neki ispitanici previde. Konačno, sem u drugoj grupi, većina ispitanika nije uočila kolokaciju reach a decision, jer se u tekstu javila i kolokacija make a decision koju ispitanici znaju, pa su je lako uočili, zanemarivši drugu mogućnost reach a decison. U drugoj grupi, gde je u listi kao sekundarni kolokat data samo reč reach, ispitanici su uspeli da je uoče i u tekstu. Ispitanici iz sve tri grupe rekli su da im je tekst bio težak, ali ne i zadatak.

\subsection{Rezultati testa kratkoročne retencije}

Rezultati testa kratkoročne retencije, odnosno broj tačnih odgovora po grupama za svaku kolokaciju dati su u Tabeli 3 .

\begin{tabular}{lllll}
\hline Kolokacija & $\begin{array}{l}\text { Prva } \\
\text { grupa }\end{array}$ & Druga grupa & Treća grupa & UKUPNO \\
\hline RUN A MEETING & 8 & 8 & 9 & 25 \\
\hline SEEK INPUT & 4 & 5 & 2 & 11 \\
\hline REACH A DECISION & 4 & 7 & 4 & 15 \\
\hline STICK TO THE & 9 & 9 & 10 & 28 \\
SCHEDULE & & & & 18 \\
\hline CREATE AN AGENDA & 6 & 6 & 6 & 22 \\
\hline DELEGATE TASKS & 8 & 6 & 8 & 10 \\
\hline ESTABLISH RULES & 4 & 3 & 3 & 129 \\
\hline UKUPNO: & 43 & 44 & 42 & \\
\hline
\end{tabular}

Tabela 3. Broj tačnih odgovora na testu kratkoročne retencije

Rezultati testa kratkoročne retencije pokazuju da nema statistički značajne razlike među grupama $(\mathrm{N}=32, \mathrm{p}=.525, \mathrm{~F}(2,29)=.660)$. Deskriptivna statistika pokazuje sledeće rezultate: 1 . grupa $\mathrm{M}=3.9 \mathrm{SD}=1.44 ; 2$. grupa $\mathrm{M}=4.6 \mathrm{SD}=1.89$; 3. grupa $\mathrm{M}=3.81 \mathrm{SD}=1.72$ ). Dakle, prevodni ekvivalent kao način isticanja kolokacija nema pozitivan uticaj na kratkoročnu retenciju u odnosu na druga dva načina isticanja kolokacija.

Kako narušen proces obrade informacija predstavlja metakognitivni uspeh jer motiviše učenika da usmeri više pažnje na problem (Brown 1980 u Garner 
1990: 518), očekivalo se da uspeh i prve dve grupe ispitanika na testu kratkoročne retencije bude bolji od postignutih rezultata na testu uočavanja kolokacija u tekstu. Drugim rečima, pažnja ispitanika prve i druge grupe bila je već u prvom zadatku usmerena na ciljne kolokacije, ispitanici su imali mogućnost da provere odgovore zadatka prevođenja srpskih kolokacija u tekstu (prva grupa), odnosno zadatka spajanja kolokata u cilju dobijanja tačnih kolokacija (druga grupa), uoče svoje greške i tako poboljšaju retenciju. Stoga bi se dobijeni rezultati mogli objasniti pretpostavkom da se izvestan broj ispitanika prve i druge grupe oslanjao samo na jedan od kolokata i, posle njegovog uočavanja, mehanički obeležavo kolokaciju bez dublje analize njenog značenja. Druga mogućnost jeste da osobine elemenata kolokacije utiču na retenciju. Naime, vidi se da su rezultati po kolokacijama relativno slični u sve tri grupe. Dakle, moguće je da je u prvom zadatku kolokacija ostala neprimećena u trećoj grupi, jer je zadatak bio kognitivno zahtevniji, ali da je pri drugom susretu sa kolokacijom u toku provere razumevanja teksta (u kojoj je cilj takođe bio skretanje pažnje na ciljne kolokacije) osobina kolokacije uticala na retenciju.

Nešto lošiji rezultat uočen je kod kolokacije run a meeting u prvoj grupi. Analiza grešaka pokazuje da su neki ispitanici ponovo koristili lead ili hold a meeting. Odgovor ispitanika na pitanje da objasne zbog čega nisu koristili glagol run, bio je: pa može i lead. Dakle, kao i kada je reč o drugim aspektima jezika, učenici često nisu motivisani da proširuju svoje znanje u trenutku kada smatraju da jezičkim sredstvima koje već poseduju mogu da ostvare komunikaciju. U slučaju kolokacije reach a decision javlja se make a decision u nekoliko slučajeva. Kako je jedno istraživanje već pokazalo, ispitanici imaju manje poteškoća u usvajanju kolokacije u kojima je sekundarni kolokat semikopulativni glagol (Chan \& Liou 2005), te je moguće da imaju produktivno znanje samo ovog kolokata. Reč establish ispitanici su (bar većina njih) naučili nekoliko dana pre istraživanja u značenju osnovati (to establish a company), ali se među odgovorima ponovo nalazi make, bring.

S druge strane, više od polovine ispitanika znalo je na testu kolokaciju to create an agenda. Prema rečima ispitanika, ovaj spoj je veoma neobičan ako se bukvalno prevede. Slično objašnjenje ispitanici su dali i za kolokaciju delegate tasks. Dakle, činjenica da je kolokacija kako studenti kažu neobična i zanimljiva kada se bukvalno prevede, uticala je da bude lakše uočena i zapamćena. Najbolji rezultati uočavaju se kada se radi o kolokaciji stick to the schedule. Mada je ova kolokacija bila lako uočljiva u tekstu i svi ispitanici sigurno znaju glagol stick to, ipak nije jasno zbog čega su rezultati bolji nego kada je u pitanju kolokacija npr. 
run a meeting, koja se javila nekoliko puta u tekstu. Ponovo se najlošiji rezultati uočavaju kod kolokacije seek input.

Konačno, pregledom grešaka, uočava se uticaj srpskog jezika u nekoliko slučajeva, npr. ask input, bring a decision, bring a few ground rules, set tasks, hold to the schedule.

\section{ZAKLJUČAK I PEDAGOŠKE IMPLIKACIJE}

Specifičnosti svakog jezika ponaosob, najčešće onemogućavaju da neizvorni govornik na osnovu maternjeg jezika predvidi koji jezički spoj predstavlja prihvatljivu kolokaciju. Mnoga istraživanja pomenuta na početku rada, bez obzira na to da li govore u prilog holističkom pristupu (usvajanja kolokacija kao jedne celine) ili analitičkom (analiza forme i sadržine kolokata), ističu značaj usmeravanja pažnje učenika na kolokacije u stranom jeziku.

U ovom istraživanju cilj je bio da se ispita da li postoji prednost usmeravanja pažnje na nove kolokacije u tekstu pomoću njihovog srpskog prevodnog ekvivalenta u odnosu na povezivanje ponuđenih kolokata i tehniku samostalnog uočavanja svih kolokacija u tekstu. Rezultati pokazuju da ova tehnika daje slične rezultate u uočavanju kolokacija kao i tehnika povezivanja kolokata. Razgovor sa ispitanicima pokazuje da su studenti, za pronalaženje ciljne kolokacije u tekstu, koristili strategije predviđanja mogućih spojeva na osnovu značenja jednog kolokata i provere značenja na osnovu konteksta ili zaključivanje značenja cele kolokacije, kao bilo koje druge lekseme, na osnovu konteksta. Najlošiji rezultati dobijeni su u grupi koja je samo dobila zadatak da uoči sve kolokacije u tekstu, jer su na raspolaganju imali manji broj primenljivih strategija. U ovoj grupi se vidi da ispitanici u tekstu teže uočavaju kolokacije ukoliko su kolokati formalno razdvojeni, tj. modifikovani pridevom (establish ground rules, run a successful meeting) ili ukoliko je glagol podvrgnut transformaciji, u ovom istraživanju $\mathrm{u}$ obliku prošlog participa (task delegated).

Rezultati testa kratkoročne retencije takođe ne ukazuju na prednost prevodnog metoda. Test kratkoročne retencije u svim grupama ukazuje na to da se ispitanici oslanjaju na srpski jezik ukoliko ne znaju tačan odgovor, kao i da se najbolji rezultati uočavaju kod onih kolokacija koje su ispitanicima 'neobične' i time u velikoj meri vidljive.

Dakle, utisak nekih studenata da prevodni ekvivalent ima značajan efekat na uočavanje i retenciju novih kolokacija ukazuje na činjenicu da ova tehnika doprinosi razvijanju svesti o razlikama među jezicima, kao i da korišćenje prevodnog ekvivalenta nekim učenicima više odgovara nego preostala dva. Stoga, 
pri obradi kolokacija, kao i kod usvajanja bilo kog drugog jezičkog materijala, treba koristiti različite tehnike, imajući u vidu činjenicu da učenici poseduju različite strategije i stilove učenja. Istraživanje dalje potvrđuje da uočavanje kolokacija nije garancija da će one biti i usvojene, jer primećivanje jeste prvi korak neophodan za usvajanje novih ustaljenih jezičkih spojeva, ali ne znači da će svaki primećeni element nužno biti i zapamćen (Boers et al. u Laufer \& Waldman 2011: 666). Zato je neophodno osigurati velik broj aktivnosti u nastavi kako bi se kolokacije usvojile.

Istraživanje ima nekoliko nedostataka: mali broj ispitanika i mali broj ispitivanih kolokacija. Najveći nedostatak, pak, predstavlja činjenica da je izostala detaljnija kvalitativna analiza kojom bi se dobili detaljniji podaci većeg broja ispitanika o tome šta ih je motivisalo u rešavanju zadataka, kako su im pristupili, koje strategije su koristili, kakav stav imaju o određenom pristupu, itd., što bi značajno doprinelo efikasnijoj obradi kolokacija u nastavi.

\section{LITERATURA}

Bahns, J. (1993). Lexical collocations: a contrastive view. ELT Journal 47 (1): 5663.

Chan, T. \& H. Liou (2005). Effects of Web-based Concordancing Instruction on EFL Students' Learning of Verb - Noun Collocations. Computer Assisted Language Learning 18 (3): 231-250.

Dorkchandra, D. (2015). The Effects of Instruction of Noticing Collocation on Thai EFL Learners. Journal of Advances in English Language Teaching 1 (3): $1-11$.

Durrant, Ph. \& N. Schmitt (2010). Adult learners' retention of collocations from exposure. Second Language Research 26 (2): 163-188.

Ellis, N. (2003). Constructions, Chunking, and Connectionism : The Emergence of Second Language Structure, in The Handbook of Second Language Acquisition, eds. C. J. Doughty \& M. H. Long (Malden: Blackwell Publishing): 63-103.

Garner, R. (1990). When Children and Adults Do Not Use Learning Strategies: Toward a Theory of Settings. Review of Educational Research 60 (4): $517-$ 529.

Henriksen, R. (2013). Research on 12 learners' collocational competence and development - a progress report, in L2 Vocabulary Acquisition, Knowledge and Use New Perspectives on Assessment and Corpus Analysis, eds. C. 
Bardel, C. Lindqvist, B. Laufer (Amsterdam: European Second Language Association): 29-56.

Yamashita, J. \& N. Jiang, (2010). L1 Influence on the Acquisition of L2 Collocations: Japanese ESL Users and EFL Learners Acquiring English Collocations. TESOL Quarterly 44 (4): 647-668.

Laufer, B. \& N. Girsai (2008). Form-focused Instruction in Second Language Vocabulary Learning: A Case for Contrastive Analysis and Translation. Applied Linguistics 29 (4): 694-716.

Laufer, B. (2011). The Contribution of Dictionary Use to the Production and Retention of Collocations, in A Second Language. International Journal of Lexicography 24 (1): 29-49.

Laufer, B. \& T. Waldman (2011). Verb-Noun Collocations in Second Language Writing: A Corpus Analysis of Learners' English. Language Learning 61 (2): 647-672.

Liou, H. \& T. Chan (2005). Effects of Web-based Concordancing Instruction on EFL Students' Learning of Verb - Noun Collocations. Computer Assisted Language Learning 18 (3): 231-250.

Liu, D. (2010). Going Beyond Patterns: Involving Cognitive Analysis in the Learning of Collocations. TESOL Quarterly 44 (1): 4-30.

Longman Dictionary of Contemporary English Online. Pristupljeno 28. 11. 2018. URL: <http://www.ldoceonline.com>.

Hulstijn, J. \& B. Laufer (2001). Some Empirical Evidence for the Involvement Load Hypothesis in Vocabulary Learning. Language Learning 51 (3): 539558.

Hulstijn, J. (2003). Incidental and Intentional Learning, in The Handbook of Second Language Acquisition, eds. C. J. Doughty \& M. H. Long (Malden: Blackwell Publishing): 349-381.

Macis, M. \& N. Schmitt (2017). The figurative and polysemous nature of collocations and their place in ELT. ELT Journal 71 (1): 50-59.

McCarthy, M. (1990). Vocabulary. Oxford: OUP.

Makinina, O. (2017). Factors Impacting Recognition of False Collocations by Speakers of English as L1 and L2. TESL Canada Journal 34 (3): 165-191.

Martynska, M. (2004). Do English language learners know collocations? Investigationes Linguisticae 11: 1-12.

Nation, I. S. P. (2001). Learning Vocabulary in Another Language. Cambridge: CUP.

Nesselhauf, N. (2003). The Use of Collocations by Advanced Learners and Some Implications for Teaching. Applied Linguistics 24 (2): 223-242. 
Online Oxford Collocation Dictionary. Pristupljeno 28. 11. 2018. URL: $<$ http://www.freecollocation.com>.

Peters, E. (2012). Learning German formulaic sequences: the effect of two attention-drawing techniques. The Language Learning Journal 40 (1): 6579.

Prćić, T. (1997). Semantika i pragmatika reči. Sremski Karlovci, Novi Sad: Izdavačka knjižarnica Zorana Stojanovića.

Schmidt, R. (1993). Awareness and Second Language Acquisition. Annual Review of Applied Linguistics 13: 206-226.

Wray, A. (2000). Formulaic Sequences in Foreign Language Teaching. Applied Linguistics 21 (4): 463-489.

Nataša B. Bikicki

Novi Sad School of Business

\section{THE EFFECT OF SERBIAN TRANSLATION EQUIVALENTS ON NOTICING AND SHORT-TERM RETENTION OF ENGLISH COLLOCATIONS}

\section{Summary}

The aim of this paper was to examine whether providing the Serbian equivalent of English verb+noun collocations prior to reading the text has any advantages on noticing new collocations in the text over other two attention-drawing techniques (1) matching the elements of target collocations prior to reading the text, and (2) simply directing students' attention to finding collocations in the text. The research further aimed to determine if providing the Serbian equivalent of English collocations prior to reading the text is more beneficial to short-term retention compared with the other two techniques. The research was based on the assumption that the attempt to translate the Serbian collocations and then look for the correct answers in the text would engage students in a task that requires the application of various strategies that lead to better short-term retention. Thirty-two firstyear undergraduate business school students took part in the study. Seven frequent collocations in business English were chosen as target items. The results did not show a statistically significant advantage of Serbian translation equivalents either as regards noticing the number of target items in the text or the recall on the immediate gap-filling test. The immediate test in all three groups revealed that students tend to rely on their mother tongue (L1) when they lack the knowledge of an English collocation. It further showed that students have better retention of more salient collocations. The whole-class discussion revealed that, as expected, the students used various strategies to complete the task, yet the lack of other qualitative techniques prevented the researcher from gaining more insights into the problem.

Key words: collocation, short-term retention, matching, translation equivalent, strategies, text, noticing. 
DODATAK 1: TEKST

SEVEN TIPS FOR RUNNING A SUCCESSFUL MEETING

Meetings fill an increasing number of hours in the workday, and yet most employees consider them as a waste of time. But there are ways to run effective, efficient meetings. Here are some tips:

1. A meeting must have a specific and defined purpose. Before you send that calendar invite, ask yourself: What do I seek to accomplish? Are you alerting people to a change in management or a shift in strategy? Are you seeking input from others on a problem facing the company? Are you looking to reach a decision on a particular matter?

2. When you're calling a meeting, take time to think about who really needs to be there. When people feel that what's being discussed isn't relevant to them, or that they lack the skills or expertise to be of assistance, they'll feel they are wasting their time.

3. Stick to your schedule. Create an agenda that lays out everything you plan to cover in the meeting. Once you're in the meeting, put that agenda up on a screen for others to see. This keeps people focused.

4. If you notice one person monopolizing the conversation, call him out. Say, "We appreciate your contributions, but now we need input from others before making a decision." Establishing ground rules early on will create a framework for how your group functions.

5. If you have a reputation for being someone who starts and ends promptly, you will be amazed how many of your colleagues will make every effort to attend your meetings.

6. Ban technology. The reality is that if people are allowed to bring iPads or BlackBerries into the room, they won't be focusing on the meeting or contributing to it.

7. It's quite common for people to come away from the same meeting with very different interpretations of what went on. To reduce this risk, email a memo to all who attended within 24 hours after the meeting. Document the responsibilities given, tasks delegated, and set deadlines.

Meetings truly can be valuable and productive. You just have to take the steps to make them that way. 
DODATAK 2: TEST KRATKOROČNE RETENCIJE

ŠIFRA.

Dopunite rečenice odgovarajućim glagolom kako biste dobili kolokaciju koju ste sreli $\mathrm{u}$ tekstu. Svaki glagol možete koristiti samo jednom: give, ask, make, run, do, bring, seek, lead, create, stick, delegate, hold, establish, reach.

1. I always input from my colleagues before making a decision.

2. Can you give me some advice on how to a good meeting agenda?

3. Every manager needs to learn how to meetings.

4. A manager needs to tasks. They simply can't do everything on their own

5. I find it difficult to to the schedule.

6. First, we need to a few ground rules.

7. We had a long meeting yesterday but we didn't a decision.

Primljeno: 23. 4. 2020.

Prihvaćeno: 12. 8. 2020. 